\title{
THE EFFECTS OF USING EDMODO IN BIOLOGY EDUCATION ON STUDENTS' ATTITUDES TOWARDS BIOLOGY AND ICT
}

\author{
Veronika Végh \\ University of Pecs, Hungary \\ E-mail: vegvera@msn.com
}

Zsolt B. Nagy

Guppi Consulting Ltd, Hungary

E-mail: dr.nagy.zsolt@gmail.com

Csilla Zsigmond

Hungarian Human Rights Foundation, Hungary

E-mail: cszsigmond@yahoo.com

Gábor Elbert

University of Pecs, Hungary

E-mail: elberteam@gamil.com

\begin{abstract}
ICT has gained a vital role within education, helping to facilitate the teaching-learning process. This paper examines the efficacy of the Edmodo interface within biology education in high schools. Two $10^{\text {th }}$ grade classes were studied for a one semester period. Both classes followed the same curriculum, however Edmodo usage was compulsory for the experimental class. Anonymous pre-and post-test questionnaires were filled out by the students and statistically analyzed. The research included 58 students; 34 females and 24 males. Over the course of the semester, the experimental group developed increased feelings of importance towards Biology, whereas no change was observed in the control group. At the end of the semester, the experimental group scores leant favorable towards the positive impact of Edmodo use in the classroom, in comparison to the control group. These results show a positive impact of using Edmodo in the classroom, as a facilitative tool, to improve student comprehension in the participating Hungarian students.
\end{abstract}

Keywords: ICT in education, biology teaching, biology learning, Edmodo, ICT in biology teaching.

\section{Introduction}

ICT plays a fundamental role in the teaching-learning process. The Edmodo interface was designed as an educational platform and has previously been indicated to successfully foster meaningful learning (Holland \& Meilenburg, 2011; Kouloumbaritsi, Dimitroglou, Mavrikaki \& Galanopoulou, 2013; Thongmak, 2013; Nee, 2014; Al- Kathiri, 2015). The main purpose of this study was to look at Edmodo usage within Biology teaching and to examine how six months of Edmodo application can influence students' attitudes towards Biology and ICT.

\section{ICT in Education}

In the $21^{\text {st }}$ century, internet use is wide-spread among all societal groups, having both positive and negative effects. On the positive side, several studies have emphasized higher 
Veronika VÉGH, Zsolt B. NAGY, Csilla ZSIGMOND, Gábor ELBERT. The effects of using Edmodo in biology education on students' attitudes towards biology and ICT

PROBLEMS

OF EDUCATION

IN THE $21^{\text {st }}$ CENTURY Vol. 75, No. 5, 2017

484

levels of intelligence, better cognition and/or better grades amongst users. However, internet usage patterns show a correlation with personality traits as well (Subrahmanyam, Kraut, Greenfield \& Gross, 2001). Internet access is readily available for the majority of the population on personal computers (PC) phones, watches and on other devices. As a consequence, learning environments and the method of knowledge acquisition have changed and multitasking has become ubiquitous. In the literature, several studies discuss the role of mobile ICTs in the education system. A separate large-sample study involving 4461 schools, 10691 teachers and 102231 students showed that using ICTs during class has a positive or neutral impact on both teachers and students (Schrack, 2014). Another study indicated that the attitude of Slovakian students towards computers is not dependent on the number of computers in schools and that females and males spend about the same amount of time in front of the computer in school. This is typically the case for older students, meaning that younger people compensate for the less time spent in front of the computer at home (Fancovicova \& Prokop, 2008).

Not only the students, but most teachers are also positive about using ICTs, although many teachers find it difficult to incorporate them into education. The lack of synchronization between education and technology is a common problem, as shown by the research based on inquiry-based pedagogy and education using ICTs carried out in the Stanford Mobile Inquiry-Based Learning Environment (SMILE). The effectiveness of the method varied across countries, but it was shown to generally change the teacher-student dynamics in the classroom, enabling the students to come forward with more questions. On the other hand, the curiosity of students is pre-determined, to a certain extent, by the educational profile of the schools and the country in question. It is generally true that this method is more difficult to use in fields where memorization is a widespread pedagogical practice (Buckner \& Kim, 2014).

Lim and Khine (2006) examined teachers' responses to difficulties arising from the use of ICTs as part of educational activities in Singaporean schools. Two primary and two secondary schools participated in the research. First-order barriers (debilitating factors not related to the teacher's person) and second-order barriers (debilitating factors preventing the positive shift in teachers' opinions about ICT) have been used to describe the difficulties of use. According to the results, the following first-order barriers were found: the difficulties to limit classes to the standard 40-45 minutes when ICT is used; the long time needed for setting up ICTs at the beginning of the class; and frustration caused by the computers, which are obsolete or insufficient in number. On the other hand, the following second-order barriers were present: some teachers felt that traditional methods were faster and more efficient than ICT; some teachers regarded ICT as a threat to traditional education; and some teachers were reluctant to share with their colleagues the difficulties experienced during the courses taught with the help of ICT (Lim \& Khine, 2006).

A Greek study examined the attitudes of 1165 teachers towards ICT (Jimoyiannis \& Komis, 2007). The majority showed a positive attitude; however, a number of factors had a negative effect on the teachers' attitudes. The respondents' opinions could be divided into three groups: positive, neutral and negative. However, gender, the curriculum and teaching experience were found to be influencing factors in this respect. Although $92 \%$ of teachers surveyed were aware of the fact that ICT is needed in today's world, more convincing reasons are needed for winning over the skeptics. One reason why some respondents had a negative opinion was that they regarded ICT as a contributing factor to the growing isolation and the shrinking of social interaction. They also mentioned that ICTs posed certain challenges in the classroom.

In Slovenia, a study involving 70 Biology teachers examined the reasons why the installation of computers and laboratory equipment in schools was not as successful as anticipated (Sorgo, Verckovnik \& Kocijancic, 2010). Researchers were able to distinguish three variables. The Biology teachers showed positive attitudes towards the elements belonging to the first category, such as the use of the internet, e-mail or MS Word, together with a willingness to use these tools for their work and at home, for preparing classroom materials. The second category included presentations, data loggers, computer programs and virtual laboratories. 
Although teachers' attitudes were also positive to the elements of this category, they neglected these tools for reasons such as the size of curricula or insufficient skills. The third category

PROBLEMS

OF EDUCATION

IN THE $21^{\text {st }}$ CENTURY

Vol. 75, No. 5, 2017 included computer games and programming, towards which teachers generally showed a negative attitude and refused to use them for their work.

Another study, conducted in England on teacher involvement, explored the difficulties related to ICTs based on the teachers' experience. Researchers found that the transfer of knowledge was not working properly with the tools, although ICT supported school education could be improved with the development of these tools (Webb, 2002). On the other hand, it has also been proved that for example Challenge Based Learning (CBL) method could be successfully promoted by ICT (Antal, 2014).

Previous research indicates that the presence of various ICTs and both teachers and students' positive attitudes open new and promising possibilities for future teaching techniques, but of course a lot of improvement must be done in order to precisely describe ICT related teaching methods that may support the teaching and learning processes.

\section{ICT in Biology Education}

In many respects, natural sciences offer special teaching and learning opportunities. Practical orientation, experimentation and the advantages of an interdisciplinary approach can be regarded as possibilities for a more effective transfer of the curriculum and for supporting knowledge acquisition. In the case of biology, the application and practice of the acquired knowledge, as well as enabling students to use their knowledge in daily life, are key considerations. Therefore, it is important that teachers approach biology education with the most effective methods. Often, the teacher is challenged not only by the lack of time, but also by the number of students present in the classroom. University biology classes are often taught in one large group instead of smaller student units (Tanner, 2011), which is also true in high schools. With appropriate methods, such as ICT-enabled online questionnaires, hundreds of students can be reached simultaneously. Pedagogical phenomena consist of increasingly complex processes. As such, the successful transfer of the curriculum depends on a large number of factors and because of this, it is desirable for teachers to take every opportunity to make biology an appealing subject.

Kubiatko wrote a detailed study about the way students view the use of ICTs by biology teachers. As part of the study, 270 Slovakian students from 9 schools filled out questionnaires. According to the students, there is a big difference between teachers with regard to the didactic tools used. The use of presentations and projectors proved to be very common, but in certain cases these tools were not used in biology class at all. The students were also asked to indicate the purpose of the use of ICT by the teacher. Two responses were marked with an exceptionally high frequency, namely the introduction of a new topic (34.44\%) and the complete lack of ICTs $(35.19 \%)$. Overall, the study shows that ICT usage is very limited in biology lessons (Kubiatko, 2006).

Kubiatko and Haláková studied Slovakian students' attitudes towards the use of ICT in biology, involving 518 high school students aged 15 to 19 (Kubiatko \& Haláková, 2009). It was found that males have responded better to ICT in biology class than females and that the attitudes of older students are more positive than that of younger ones.

After the completion of a course in the study of a three-dimensional synthetic environment, data analysis carried out with the purpose of facilitating the education of cell biology and photosynthesis indicated that the 37 teachers participating in the research considered the application of visuals during class useful (Mikropoulos, Katsikis, Nikolou \& Tsakalis, 2003). Computer mediated stimulation (CMS) programs can also enhance the students' learning outcomes about the Cell Theory (Kiboss, Ndirangu \& Wekesa, 2004). 
Veronika VÉGH, Zsolt B. NAGY, Csilla ZSIGMOND, Gábor ELBERT. The effects of using Edmodo in biology education on students' attitudes towards biology and ICT

PROBLEMS

OF EDUCATION

IN THE $21^{\text {st }}$ CENTURY Vol. 75, No. 5, 2017

ICT has changed the traditional classroom structure and contributes to the development of the learning and teaching process. The advantages of using ICTs, in the case of biology education, include facilitating visualization, streamlining the transfer of information between teachers and students, eliminating time constraints, contributing to repeatable practices, promoting teamwork and helping to overcome geographic distances. As Rotbain et al. proved in their study, a better understanding of the abstract Molecular biology concepts and processes can be achieved by the students by using computer animations. Students favored this ICT because it helped them to visualize the processes, the activity booklets made the lessons more enjoyable for them. They also emphasized the tasks' repeatability as a positive contributor of their studies (Rotbain, Marbach-Ad \& Stavy, 2008).

There are countless possibilities for synchronizing ICT and biology classes, not just computers, websites, blogs, microphones, interactive boards, digital videos, online media and digital games are popular, but smartphones, iPods, iPads and other equipment can be successfully used to promote students' academic improvement (Kagohara et al., 2013) and these tools contribute to improving biology studies (Sentilkumar, Sivapragasam \& Senthamaraikannan, 2014).

The role of ICT in biology education is difficult to precisely appraise, however, it is certain that it works as a catalyst and leads to a change in teaching style, learning methods and the availability of information (Watson, 2001).

According to the above examples, it can be seen that ICT supported biology teaching worked effectively in case of different biology classes. By improving ICT supported teaching techniques, creating more and more specific programs for biology teaching, teaching the subject could be much more effective and more enjoyable for the $21^{\text {st }}$ century generation.

\section{Edmodo}

The interactions between teachers, students and the educational material can be supported by e-learning techniques. Integrating ICT in biology education is always an opportunity for the teachers to bring nature into the science classroom and to raise the quality of education. One version of e-learning involves tools related to web-based learning, such as the Edmodo interface. Developed for educational purposes in 2008, the interface offers free and secure software that supports varied education. Teachers can create groups that students can join after being invited by the teacher or by entering a group code. Teachers can create quizzes (which can be evaluated by the system), send individual or group messages to students, manage teamwork, tasks and schedule appointments. In 2011, the interface was chosen as one of the best websites for promoting innovation and creativity while encouraging active participation and collaboration. ${ }^{1}$

As indicated in several earlier scientific publications, Edmodo is increasingly used in education (Holland \& Muilenburg, 2011).

Edmodo has been successfully used in flipped classroom scenarios as well, as a complement to biology studies (Kouloumbaritsi, Dimitroglou, Mavrikaki \& Galanopoulou, 2013). The use of the interface in biology class increases the students' motivation and enthusiasm, while facilitating the exchange of information between closed student groups. Repeatability contributes to a better understanding of biological concepts and strengthens the enthusiasm of the students, who will communicate and interact more with each other (Nee, 2014).

Edmodo has also been used to support computer-mediated communication (CMC) methods in English literature courses. Many students found Edmodo similar to Facebook, which makes it easy to use and appealing to students. By using Edmodo, students were developing better skills around asking adequate and relevant questions that others could answer in a meaningful way. The more adept they became at using Edmodo, the less teacher intervention

1 Best Websites for teaching and learning. Accessed 22 June 2017, http://www.ala.org/aasl/standards/best/websites/2011 
was needed. The author of the article recommends using the interface for teaching English and

$$
\begin{aligned}
& \text { OF EDUCATION } \\
& \text { IN THE } 21^{\text {st }} \text { CENTURY } \\
& \text { Vol. 75, No. 5, } 2017
\end{aligned}
$$

Another study looked at the use of Edmodo in ESL education among females in Saudi Arabia in a comparative manner. The experimental group used Edmodo on a daily basis for 6 weeks as part of their regular education, while the other one did not use it at all. After using Edmodo, the tendency was shown to be further increasing, even among students whose original attitudes had originally been positive towards learning foreign languages (Al-Kathiri, 2015).

Thai university students encouraged their teachers to use Edmodo to support their studies. Its resemblance to Facebook makes it easy to use but has more functionalities, developed especially for education (Thongmak, 2013) and even digital immigrant teachers were able to use this user-friendly interface effectively and confidently, not only for providing online courses, but also for offering workshops for colleagues (Kongchan, 2012).

Based on the results of this study, that Edmodo promotes efficient development of several skills. By joining different professional groups, teachers can develop their skills and broaden their knowledge. These professional groups are formed with the participation of subject teachers and other experts in the field, who are free to comment the topics. Also, Edmodo can be used for the efficient planning of pedagogical processes and activities as well. In this respect, there is a usefulness behind posting quizzes created on the interface within their relevant learning areas. Support for learning is clearly accomplished by providing online quizzes for students, the results of which are immediately evaluated by the system. Student groups and communities develop from the creation of an online classroom within the Edmodo system, where children are in constant contact with each other and the teacher.

It is important to emphasize that the present research focuses on the development of foreign language competence, science competence, digital competence, effective self-learning and core social competencies through the use of Edmodo as well. The development of these competencies contributes to the development of a healthy self-image and supports the specific learning processes of the digital generation (Prensky, 2001). In addition to that, the use of ICTs promotes self-regulated learning, as well as motivates and encourages interdisciplinary thinking. Visualization has long been emphasized in biology education, a method that is easy to incorporate into online education.

\section{The Purpose of the Research}

In Hungary, like many other countries, ICT-supported education methods are rapidly gaining ground. Online classrooms broaden this repertoire, contributing to the development and learning of students in the $21^{\text {st }}$ century. As ICTs are no longer an exclusive part of computer science lessons, all teachers should become familiar with the opportunities presented by these tools and use them in a variety of courses.

The aim of experimental research was to examine the impact of using Edmodo for one semester in biology classes of tenth grade students, who were studying the subject in English. The change in their attitude towards the subject was examined, as well as the development of their opinion about the use of ICTs in biology class.

By analyzing the frequency of Edmodo usage in the control group during the semester, mapping the frequency of using other ICTs and assessing the students' views on the compatibility of ICT and biology education, clear answers could be provided to the two main questions, as follows:

1. How did the use of Edmodo affect the attitude of the class towards biology and ICT?

2. Students of which learning style are able to make better use of the opportunities offered by ICT in biology learning?

The following hypotheses were tested:

1. The use of Edmodo has a positive influence on the students' interest in biology. 
Veronika VÉGH, Zsolt B. NAGY, Csilla ZSIGMOND, Gábor ELBERT. The effects of using Edmodo in biology education on students' attitudes towards biology and ICT

OF EDUCATION

IN THE $21^{\text {st }}$ CENTURY Vol. 75 , No. 5, 2017

488

2. Students believe that the use of ICTs has a positive influence on their biology studies.

3. The students' style of learning highly influences their attitude towards ICT.

\section{Methodology of Research}

\section{General Background}

In Hungary, secondary school usually lasts for four years, in classes 9 to 12 of public education. The experiment involved two $10^{\text {th }}$ grade classes, with 58 students altogether. Under the framework curriculum included in Annex 3 of Decree No 51/2012 (XII 21) on the goals, thematic units and maximum number of classes, issued by the Ministry of Human Capacities, all of the students studied the subject in English twice a week.

\section{Sample of Research}

Two classes participated in the research from two Hungarian secondary grammar schools. Directorial permissions for research were obtained. A total of 58 students participated in the research. The control group consisted of 35 students ( 23 females and 12 males) while there were 23 pupils in the experimental group (11 females and 12 males). The average age of the students was 16.9 years (16.8 in the control group and 17.0 in the experimental group) (Table 1.). Table 1 shows that students in the experimental and control groups had been studying biology for a similar amount of time (3.1-3.2 years, respectively).

Table 1. Number of individuals, gender distribution, average age of students and years of biology study in the control and experimental group.

\begin{tabular}{lll}
\hline & Control group & Experimental group \\
\hline Headcount (people) & 35 & 23 \\
\hline Females / Males & $23 / 12$ & $11 / 12$ \\
\hline Average age & 16.8 & 17.0 \\
\hline Years of studying biology & 3.24 (SD: 0.53) years & 3.07 (SD: 2.14) years \\
\hline
\end{tabular}

\section{Instrument and Procedures}

The research took place between January and June 2016 involving an experimental and a control group, in two classes of two separate institutions. The same curriculum was taught in both groups and the same tasks were used for testing the two classes. Students were asked to complete anonymous, paper-based questionnaires before and after the study during their lessons. The instruments were distributed among the students by the teachers.

The questionnaire was related to the research topic in several aspects. The pre-test was longer than the post-test, taken in June. The pre-test aimed at collecting general information about the students, such as gender, year of birth, length of biology studies or favorite subjects and also their learning style, which was determined by filling in Imre Szitó's learning style questionnaire (Tóth, 2004). It was carried out with a five-level Likert scale questionnaire with 34 statements and the answers were used to estimate the students' learning style (auditory, visual, kinesthetic, interpersonal, intrapersonal or mixed). 
These were not a part of the questionnaire in June, but all the other questions were included. The next part of the questionnaire examined the frequency of ICT usage of common ICTs (Kubiatko \& Haláková, 2009). Further questions about ICT importance in education and in biology classes were asked. Students were quizzed about their internet habits and the usage frequency of social network portals. Information was requested about their biology grades that they achieved during the semester. Biology attitude testing was carried out with the application of a six-level Likert scale questionnaire created on the basis of Prokop et al.'s biology attitude questionnaire (Prokop, Tuncer \& Chudá, 2007), completed with important information with regard to the current research. The questionnaire was originally created in Hungarian and then translated into English.

\section{Data Analysis}

To be able to analyze effects of Edmodo usage on students' attitudes towards biology and ICT, besides social background data, three sets of variables from the questionnaire were analyzed. Data analysis was conducted with IBM SPSS v20 software. Three sets of variables are as follows:

1) Learning style data, employing the categorization methodology of Szitó (2019).

2) Biology attitudes question block (36 questions altogether

3) Variables measuring the usage of different ICTs (whether respondents use them at least once a month).

For the purpose of preparing the attitude data for further analysis, data reduction methodology (factor analysis) was employed on variables of the biology question block. Using the maximum likelihood algorithm, 3 factors could have been separated containing 10 original variables altogether, keeping $59.17 \%$ of their original information. These factors were evaluated on a scale of 1 to 5 (where a grade of 5 indicates full agreement with the statement in question):

1. Importance of biology as a subject (those who think that Biology education is important for them personally will score high for this factor, close to 5) This factor consists of the following variables (attitude questions):

- I like Biology more than other subjects.

- I would like to have Biology lessons more often.

- I would like to be a Biologist.

- Biology is one of the easiest courses for me.

- Biology knowledge is necessary for my future career.

2. The facilitating effect of ICTs (those who think that the use of ICTs facilitates biology education will score high for this factor, close to 5). This factor consists of the following variables (attitude questions):

- When I study biology I often use the internet for performing online tests.

- With the help of the computer I can prepare for the biology final tests in less time.

3. The debilitating effect of ICTs (those who think that the use of ICTs interferes with biology education will score high for this factor, close to 5) This factor consists of the following variables (attitude questions):

- I would prefer using the computer less in biology classes.

- Using ICT hinders my studying of biology because I have to pay attention to more things.

- ICT makes biology classes more interesting and useful 
Veronika VÉGH, Zsolt B. NAGY, Csilla ZSIGMOND, Gábor ELBERT. The effects of using Edmodo in biology education on students' attitudes towards biology and ICT

PROBLEMS

OF EDUCATION

IN THE $21^{\text {st }}$ CENTURY

Vol. 75, No. 5, 2017

\section{Results of Research}

\section{The Effects of Using Edmodo on Attitudes towards ICTS}

While answering the first question ('How did the use of Edmodo affect the attitude of the class towards biology and ICT?'), the difference between answers provided for the pre-test (January) and the post-test (June) questionnaires in the two groups was looked at, after applying data reduction method (factor analysis) through questions regarding students' attitudes towards the subject of biology.

The research showed that in both groups, a little more than one tenth of the students indicated biology as their favorite subject (13\%-11\%, respectively) (Figure 1.).

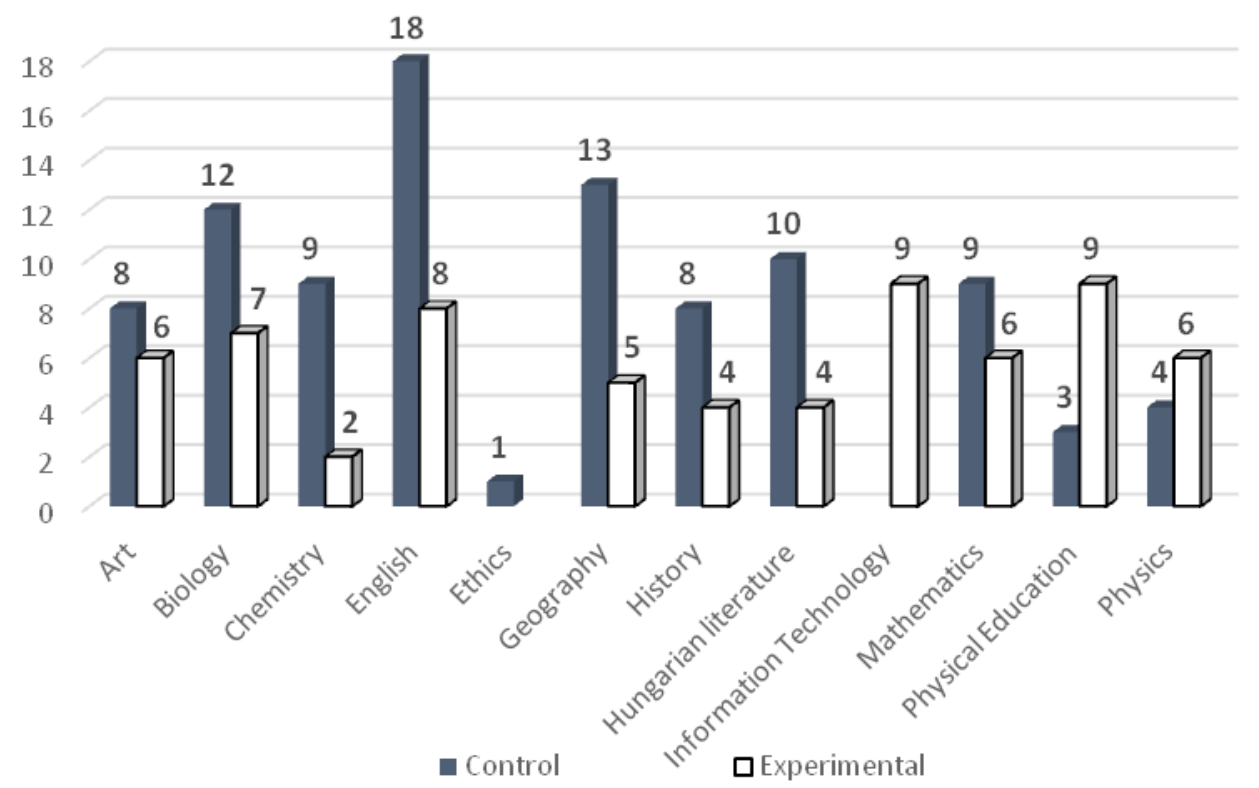

\section{Figure 1: Favourite subjects of the students in the control and experimental group.}

Figure 2 summarizes the January (pre-test) and June (post-test) factor values for the experimental and the control group. For the first factor, averages indicate that, while the initial values were similar, changes occurred in both the experimental and the control group, but the difference between the January and the June data is much greater in the experimental group. Therefore, after using Edmodo, the students' opinions about the importance of biology as a subject shifted towards the positive range, as opposed to the stagnation/slight decrease in the control group.

The second factor focuses on the facilitating effects of ICT in biology education. Looking at the changes in the averages for the two groups, it emerges that there was a positive shift in both groups; however, examining the initial values, it emerges that the experimental group had more positively viewed the presence of ICT in biology classes from the beginning.

The third factor measures the debilitating effects of using ICT. As regards class averages, it emerges that there was a minimal decrease in the experimental group, meaning that a fewer number of students thought during post-test (than during pre-test) that using ICTs had negatively affected their biology studies, while in the control group there was an increase compared to the initial value. 


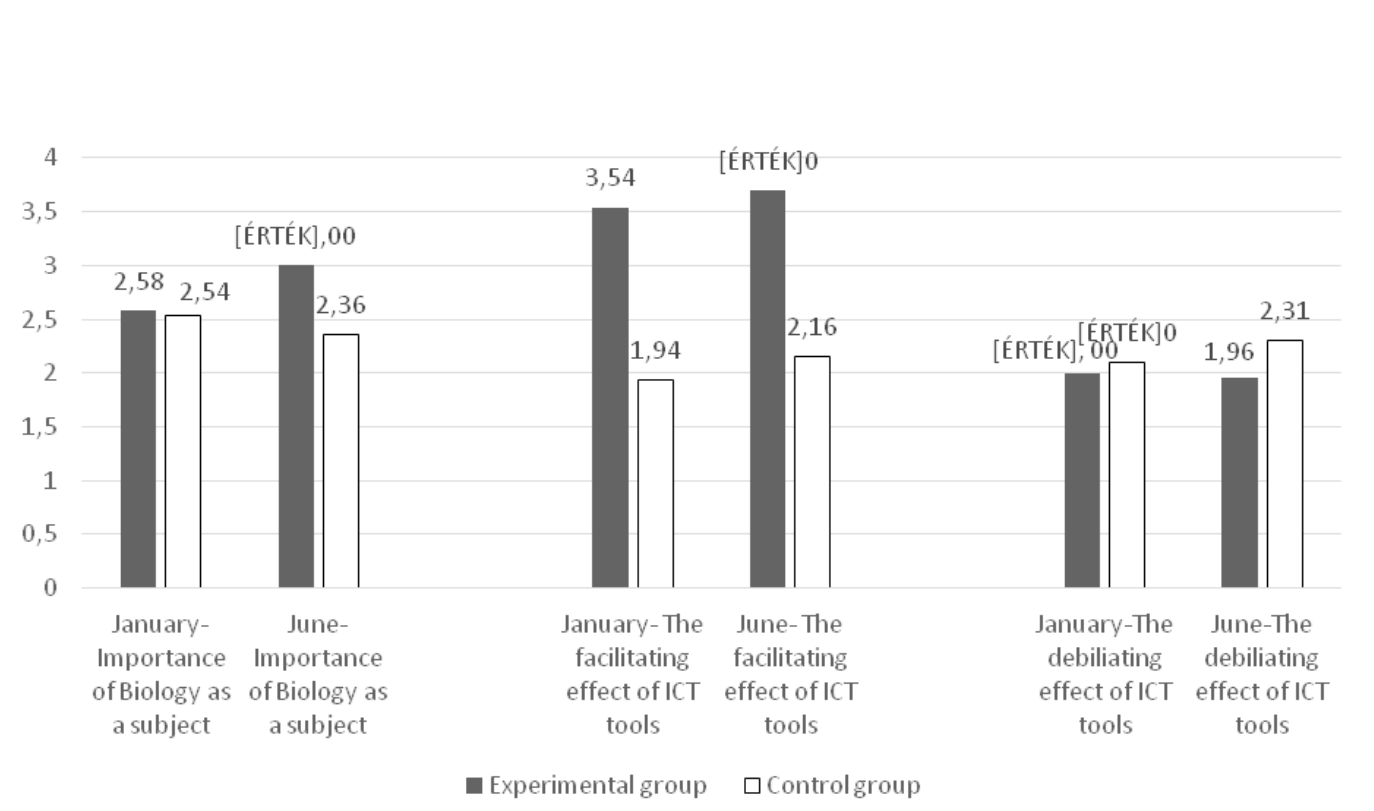

\section{Figure 2: Average factor values in January and June in the experimental and control group.}

The Effect of Using ICT on Students with Different Learning Styles

In order to provide a comprehensive answer to our second question, a detailed analysis of the students' answers for the learning style questionnaire was carried out. Table 2. summarizes the vast differences between the students learning styles. The majority of students' learning style was auditory (20.5), visual (19.9) or kinesthetic (21.6) and the number of students belonging to each different category was almost the same in the experimental and the control group as well as in gender breakdown.

Table 2. The learning style of female and male students in the experimental and control group.

\begin{tabular}{llllll}
\hline \multirow{2}{*}{ Learning style } & \multicolumn{2}{c}{ Experimental } & \multicolumn{2}{c}{ Control } & Total \\
\cline { 2 - 5 } & Male $(\%)$ & Female $(\%)$ & $\begin{array}{l}\text { Male } \\
(\%)\end{array}$ & $\begin{array}{l}\text { Female } \\
(\%)\end{array}$ & \\
\hline Auditory & 20.8 & 20.5 & 19.2 & 21.0 & 20.5 \\
\hline Visual & 19.6 & 20.3 & 19.3 & 20.1 & 19.9 \\
\hline Kinesthetic & 22.8 & 21.2 & 21.3 & 21.2 & 21.6 \\
\hline Interpersonal & 13.3 & 10.5 & 10.6 & 10.9 & 11.2 \\
\hline Intrapersonal & 13.8 & 15.0 & 13.4 & 15.2 & 14.5 \\
\hline Impulsive & 15.3 & 14.2 & 13.5 & 13.5 & 14.0 \\
\hline Mechanical & 12.6 & 12.2 & 9.3 & 11.6 & 11.4 \\
\hline
\end{tabular}

In answering the second question ('Students of which learning style are able to make better use of the opportunities offered by ICT in biology learning?'), descriptive statistical methods were applied. Looking at the averages (Table 3.), it emerges that the students whose learning style is auditory feel that ICTs facilitate their studies to a large degree. The values were lowest among the intrapersonal students, meaning that they feel that ICT does little to help their studies of biology. 
Veronika VÉGH, Zsolt B. NAGY, Csilla ZSIGMOND, Gábor ELBERT. The effects of using Edmodo in biology education on students' attitudes towards biology and ICT

PROBLEMS

OF EDUCATION

IN THE $21^{\text {st }}$ CENTURY Vol. 75 , No. 5, 2017

492

Table 3. Connection between students' learning styles and the 3 factors.

\begin{tabular}{lllll}
\hline $\begin{array}{l}\text { Learning } \\
\text { style }\end{array}$ & $\mathbf{N}$ & $\begin{array}{l}\text { ICT } \\
\text { facilitating }\end{array}$ & $\begin{array}{l}\text { ICT } \\
\text { debilitating }\end{array}$ & $\begin{array}{l}\text { Importance of } \\
\text { biology }\end{array}$ \\
\hline Auditory & 2 & 3.75 & 1.83 & 2.40 \\
\hline Visual & 30 & 2.58 & 1.96 & 2.75 \\
\hline Kinesthetic & 3 & 2.50 & 2.78 & 2.80 \\
\hline Interpersonal & 1 & 2.50 & 1.00 & 1.80 \\
\hline Intrapersonal & 17 & 2.32 & 2.25 & 2.25 \\
\hline Mixed & 4 & 3.25 & 2.08 & 2.55 \\
\hline Total & 57 & 2.59 & 2.08 & 2.56
\end{tabular}

When assessing the debilitating effects of ICTs, it emerges that students with an interpersonal learning style indicated the lowest score, while students with a kinesthetic style indicated the highest. Students with a kinesthetic learning style were the most likely to indicate that the use of ICT in biology class interferes with their studies. However, considering the low values, it can be said that all groups of students, regardless of learning style, equally think that the use of ICTs has a low debilitating effect.

Analyzing the results related to the importance of biology as a subject, it emerges that students generally think that the subject is of little importance, regardless of learning style. The subject was given the highest importance by students with a kinesthetic or visual learning style.

\section{Usage Frequency of ICTs}

The average values when measuring the facilitating effects of ICTs were much higher in the experimental group than in the control group, even back in January. For the questions related to the frequency of their general use of ICT, the students gave grades on a scale of 1 to 4 , the higher grades representing higher frequency of use. Examining the general ICT use of the two groups in January and in June, it emerges that there was no change in the control group (3.01 3.01), whilst there was a negative shift in the experimental group (3.06à2.99). ICT had a higher debilitating effect in females, but its value decreased throughout the semester.

\section{Discussion}

The main aim of this research was to observe and compare the impact of Edmodo on student' attitudes within (and absent from) the classroom, between two classes studying the same curriculum. After six months of Edmodo supported biology education in the experimental group, the analysis of post-test data indicates that more students held that biology was more important than at the beginning of the semester, whilst there was no positive shift in the control group. These results support Nee's findings that Edmodo usage in biology classes promotes student enthusiasm. (Nee, 2014). This analysis can confirm the first hypothesis, that the use of Edmodo has a positive influence on the students' interest in biology, is supported by the results.

The impacts of Edmodo usage in biology education on the students' attitudes towards ICT were also considered. Both groups had a positive attitude to using ICT in biology education; however, the experimental group already had a positive attitude towards technology before the experiment commenced, due to the fact that they had previous ICT exposure (3.54-3.7 for the experimental group and 1.94-2.16 for the control group, respectively).

Furthermore, at the end of the semester, the experimental group viewed ICT in biology education as having a lower debilitating effect than the control group (2-1.96 for the experimental 
group, and 2.1-2.31 for the control group, respectively). The results of this research confirmed previous findings (Schrack, 2014) of a positive or neutral (not negative) impact of ICT on students and teachers.

This research also shows that students with a dominant auditory learning style feel that ICTs facilitate their biology studies (3.75 on a 5-level scale), while the average for this factor is much lower, as in the case of students with intrapersonal learning styles (2.32). As for ICT debilitating effects, all learning style groups think that the use of ICT has a low debilitating effect. According to these results, there is no evident relationship between the students' learning style and the ICT debilitating effect on their studies, therefore the third hypothesis (The students' style of learning highly influences their attitude towards ICT) is not fully supported by the results.

Examining the general ICT use of the two groups in January and in June, it emerges that there was no change in the control group (3.01à 3.01), but the experimental group changed negatively (3.06à2.99). ICT had a higher debilitating effect for females, but its value decreased throughout the semester. This data confirmed the findings of Kubiatko and Haláková, according to which boys respond better to ICT in biology class than girls (Kubiatko \& Haláková, 2009).

The joint analysis of the three factors created in the course of the research confirms that the use of the Edmodo interface helps biology education as well, makes biology more appealing and facilitates comprehension of the subject material.

\section{Conclusion}

In conclusion, this research found Edmodo and ICT usage enhanced students' academic achievements and motivation in biology. After six months of Edmodo usage in biology education, average scored towards the importance of biology factor grew in the experimental group, while the control group showed a slight negative change. Both groups showed a positive shift towards Edmodo usage and ICT integration in their education by the end of the semester.

Based on the data analysis and discussion, it can be concluded that ICT supported educational methods should be embraced in order to meet the demands of the $21^{\text {st }}$ century students and support their meaningful learning.

Therefore, all teachers should strive to increase their ICT competencies in order to be able to provide adequate education to meet the demands expressed by digital native students. The spreading of ICT and internet influence, support education and more specifically, biology education. The greatest advantage of the Edmodo interface is that it is extremely user-friendly, is easy to learn for teachers and students alike. A bonus result of our research, going beyond our original goals, was the positive feedback from the participants with regard to the use of Edmodo.

Although this research provides important insights into the relationship between the presence of Edmodo and English language biology learning, future research should use larger sample sizes to gain a more accurate representation of statistical significance.

\section{Acknowledgement}

The authors would like to thank the assistance of Mrs. Jenei Fekete Marianna Ibolya regarding the questionnaires. The authors wish to acknowledge the English language revision of Ms. Leisha Carmichael.

\section{References}

Al-Kathiri, F. (2015). Beyond the classroom walls: Edmodo in Saudi secondary school EFL instruction, attitudes and challenges. English Language Teaching, 8 (1), 189. doi:10.5539/elt.v8n1p189.

\author{
PROBLEMS \\ OF EDUCATION \\ IN THE $21^{\text {st }}$ CENTURY \\ Vol. 75, No. 5, 2017 \\ 493
}


Veronika VÉGH, Zsolt B. NAGY, Csilla ZSIGMOND, Gábor ELBERT. The effects of using Edmodo in biology education on students' attitudes towards biology and ICT

PROBLEMS

OF EDUCATION

IN THE $21^{\text {st }}$ CENTURY Vol. 75, No. 5, 2017

494

Antal, P. (2014). Mobile computing and pedagogy: The contribution of the IPAD to educational innovation. In Agria Media 2014, ICI 13, ICEM 2014 Exhibition and Conference on Information and Education 08-10 October, 2014. Eger, Eszterházy Károly College, Hungary, pp. 160-161.

Buckner, E., \& Kim, P. (2014). Integrating technology and pedagogy for inquiry-based learning: The Stanford Mobile Inquiry-based Learning Environment (SMILE). Prospects: Quarterly Review of Comparative Education, 44 (1), 99-118. doi: 10.1007/s11125-013-9269-7.

Fančovičová, J., \& Prokop, P. (2008). Students' attitudes toward computer use in Slovakia. EURASIA Journal of Mathematics, Science and Technology Education, 4 (3), 255-262.

Holland, C., \& Muilenburg, L. (2011). Supporting student collaboration: Edmodo in the classroom. Paper presented at the Society for Information Technology and Teacher Education International Conference, Nashville, Tennessee, USA. Retrieved from: https://www.learntechlib.org/p/3681.

Jimoyiannis, A., \& Komis, V. (2007). Examining teachers' beliefs about ICT in education: Implications of a teacher preparation programme. Teacher Development, 11 (2), 149-173. doi: $10.1080 / 13664530701414779$.

Kagohara, D. M., van der Meer, L., Ramdoss, S., O’Reilly, M. F., Lancioni, G. E., Davis, T. N., Sigafoos, J. (2013). Using iPods ${ }^{\circledR}$ and iPads ${ }^{\circledR}$ in teaching programs for individuals with developmental disabilities: A systematic review. Research in Developmental Disabilities, 34 (1), 147-156. doi: 10.1016/j.ridd.2012.07.027.

Kiboss, J. K., Ndirangu, M., Wekesa, E. W. (2004). Effectiveness of a computer-mediated simulations program in school biology on pupils' learning outcomes in cell theory. Journal of Science Education and Technology, 13 (2), 207-213.

Kongchan, C. (2012). How a non-digital-native teacher makes use of Edmodo. Proceedings of the 5th Edition of the International Conference "ICT for Language Learning" (pp. 207-210). 15 - 16 November, The Grand Hotel Mediterraneo, Florence, Italy.

Kouloumbaritsi, A., Dimitroglou, E., Mavrikaki, E., \& Galanopoulou, D. (2013). Action research on using flipped classroom principles to teach upper high school biology. Paper presented at the 7th International Conference in Open and Distance Learning, Athens, Greece.

Kubiatko, M. (2006). How do teachers use information and communication technology in biology teaching. In. V. Lamanauskas (Ed.), Information \& communication technology in natural science education (pp. 46-50). Šiauliai: Siauliai University Press.

Kubiatko, M., Haláková, Z. (2009). Slovak high school students' attitudes to ICT using in biology lesson. Computers in Human Behaviour, 25 (3), 743-748. doi:10.1016/j.chb.2009.02.002.

Lim, C. P., Khine, M. (2006). Managing teachers' barriers to ICT integration in Singapore schools. Journal of Technology and Teacher Education, 14 (1), 97-125.

Mikropoulos, T. A., Katsikis, A., Nikolou, E., \& Tsakalis, P. (2003). Virtual environments in biology teaching. Journal of Biological Education, 34, 176-181. doi: 10.1080/00219266.2003.9655879.

Nee, C. K. (2014). The effect of educational networking on students' performance in biology. International Journal on Integrating Technology in Education, 3 (1), 21-41.

Prensky, M. (2001). Digital natives, digital immigrants Part 1. On the Horizon, 9 (5), 1-6. doi: $10.1108 / 10748120110424816$.

Prokop, P., Tuncer, G., \& Chudá, J. (2007). Slovakian students' attitudes toward biology. EURASIA Journal of Mathematics, Science and Technology Education, 3 (4), 287-295.

Rotbain, Y., Marbach-Ad, G., \& Stavy, R. (2008). Using a computer animation to teach high school molecular biology. Journal of Science Education and Technology, 17 (1), 49-58.

Schrack, C. (2014). The Austrian network of schools in mobile (e)Learning. Paper presented at the UNESCO High-Level Policy Workshop on ICT in Education for Eastern and Central European Countries, 15 -16 April 2014, Paris. Retrieved from: http://www.unesco.org/education/ICTWorkshop2014-day1/AustrianNetwork-ofSchoolsinmobileLearning.pdf.

Senthilkumar, R., Sivapragasam, C., Senthamaraikannan, B. (2014). Role of ICT in teaching biology. International Journal of Research, 1 (9), 780-788.

Sorgo, A., Verckovnik, T., \& Kocijancic, S. (2010). Information and communication technologies (ICT) in biology teaching in Slovenian secondary schools. EURASIA Journal of Mathematics, Science and Technology Education, 6 (1), 37-46.

Subrahmanyam, K., Kraut, R., Greenfield, P., \& Gross E. (2001). New forms of electronic media: The impact of interactive games and Internet on cognition, socialization, and behavior. In Singer, D. G., Singe, J. L. (Eds.), Handbook of children and the media (pp. 73-99). Thousand Oaks, CA: Sage. 
Veronika VÉGH, Zsolt B. NAGY, Csilla ZSIGMOND, Gábor ELBERT. The effects of using Edmodo in biology education on students' attitudes towards biology and ICT

Tóth, L. (2004). Pszichológiai vizsgálati módszerek a tanulók megismeréséhez [Psychological investigating methods for student recognition]. Budapest: Pedellus Tankönyvkiadó [Pedellus publisher].

Tanner, K. D. (2011). Moving theory into practice: A reflection on teaching a large, introductory biology course for majors. CBE Life Sciences Education, 10 (2), 113-122. doi: 10.1187/cbe.11-03-0029.

Thongmak, M. (2013). Social network system in classroom: Antecedents of Edmodo (C Adoption. Journal of e-Learning and Higher Education, Article ID 657749. doi: 10.5171/2013.657749.

Watson, D. M. (2001). Pedagogy before technology: Re-thinking the relationship between ICT and teaching. Education and Information Technologies, 6 (4), 251-266. doi: 10.1023/A:1012976702296.

Webb, M. E. (2002). Pedagogical reasoning: Issues and solutions for the teaching and learning of ICT in secondary schools. Education and Information Technologies, 7 (3), 237-255. doi: 10.1023/A:1020811614282.

Received: September 12, 2017

Accepted: October 25, 2017

OF EDUCATION

IN THE $21^{\text {st }}$ CENTURY

Vol. 75, No. 5, 2017

$\begin{array}{ll}\text { Veronika Végh } & \text { PhD Student, Faculty of Health Sciences, University of Pecs, Vörösmarty u. } \\ 4,7621 \text { Pecs, Hungary. } \\ \text { E-mail: vegvera@msn.com }\end{array}$

Zsolt B. Nagy PhD, Geneticist, Guppi Consulting Ltd, Bem Jozsef u. 9, 1027 Budapest, Hungary.

E-mail: dr.nagy.zsolt@gmail.com

Csilla Zsigmond

Executive Director, Hungarian Human Rights Foundation, Borbolya u. 9, 1023 Budapest, Hungary.

E-mail: cszsigmond@yahoo.com

Gábor Elbert
$\mathrm{PhD}$, Senior Lecturer, Faculty of Health Sciences, University of Pecs, Vörösmarty u. 4, 7621 Pecs, Hungary.

E-mail: elberteam@gamil.com 